\title{
Parasitism by Nematopsis sp. (Apicomplexa: Eugregarinida) in Mytella guyanensis at the Marine Extractive Reserve Baía do Iguape, Bahia, Brazil
}

\section{Parasitismo por Nematopsis sp. (Apicomplexa: Eugregarinida) em Mytella guyanensis na Reserva Extrativista Marinha Baía do Iguape, Bahia, Brasil}

\author{
Valéria Macedo Almeida CAMILO ${ }^{1,3}$, Jamille da Conceição SOUZA ${ }^{1}$, Fernanda de FREITAS ${ }^{1}$, \\ Felipe Silva de MIRANDA ${ }^{2}$, Sofia CAMPIOLO ${ }^{3}$, Guisla BOEHS ${ }^{3}$ \\ ${ }^{1}$ Universidade Federal do Recôncavo da Bahia, Centro de Ciências da Saúde, Santo Antônio de Jesus - BA, Brazil \\ ${ }^{2}$ Universidade Estadual de Santa Cruz, Departamento de Ciências Biológicas, Programa de Pós- \\ Graduação em Biologia e Biotecnologia de Microrganismos, Ilhéus - BA, Brazil \\ ${ }^{3}$ Universidade Estadual de Santa Cruz, Programa de Pós-Graduação em Desenvolvimento e Meio Ambiente, Ilhéus - BA, Brazil
}

\begin{abstract}
Several studies show the presence of protozoa of the genus Nematopsis Schneider, 1892, in many species of bivalves. The pathogenicity of this Apicomplexa is still much debated, which is possibly related to the parasitism degree and host habitat. In this context, this study investigated parasitism by Nematopsis sp. in Mytella guyanensis (Bivalvia: Mytilidae) in a mangrove of the Marine Extractive Reserve Baía do Iguape, Bahia, Brazil. The collections were made monthly, from March 2014 to March 2015, consisting of 30 adults with shell height above $40 \mathrm{~mm}$ per month, totaling 360 specimens. The specimens were measured, weighed, opened, and macroscopically examined for identifying parasites and/or signs of morphological changes. After that, they were fixed in Davidson's solution and processed according to classical histological techniques, with inclusion in paraffin, obtaining $5 \mu \mathrm{m}$-thick sections by microtomy, and stained by Harris' Hematoxylin and Eosin (HE). The water temperature ranged from 25.5 to $33.6^{\circ} \mathrm{C}$ and the salinity from 21.1 to 34.3 Practical Salinity Units (PSU). The specimens measured between 41.1 and $68.6 \mathrm{~mm}$ and had an average weight of $7.24 \mathrm{~g}$. Macroscopically, there was no presence of the parasite or any morphological changes related its presence. The frequency percentage of Nematopsis sp. was $99.45 \%$. The mantle was the organ with the highest frequency of infection (46.26\%), followed by the gonads (18.36\%). Among the analyzed organs, all presented the parasite and, in a few severely infected cases, microscopical changes were observed in the mantle conformation. The infection intensity for most of the sessions analyzed was 1 to 3 oocysts/phagocyte; however, in one of the sessions, 9 oocysts/phagocytes were recorded. The parasite had a negative correlation with salinity. The high frequency of Nematopsis sp. should be considered for the sustainability of natural stocks, especially if such parasitism occurs simultaneously with other pathogens and stressful environmental conditions. Keywords: Bivalves. Parasitism. Environmental protection area. Protozoan. Environmental sustainability.
\end{abstract}

\section{Resumo}

Diversos estudos evidenciam a presença de protozoários do gênero Nematopsis Schneider, 1892 em várias espécies de bivalves. A patogenicidade desse apicomplexo ainda é bastante debatida, a qual possivelmente relaciona-se ao grau de parasitismo e habitat do hospedeiro. Nesse contexto, este estudo investigou o parasitismo por Nematopsis sp. em Mytella guyanensis (Bivalvia: Mytilidae) em um manguezal da Reserva Extrativista Marinha Baía do Iguape, Bahia, Brasil. As coletas foram efetuadas mensalmente, de março de 2014 a março de 2015, constando 30 adultos com altura da concha acima de $40 \mathrm{~mm}$, totalizando 360 espécimens. Os espécimens foram medidos, pesados, abertos e examinados macroscopicamente para a identificação de parasitos e/ou sinais de alterações morfológicas, em seguida fixados em solução de Davidson e processados segundo técnica histológica clássica, com inclusão em parafina, obtenção de cortes de $5 \mu \mathrm{m}$ de espessura por microtomia e coloração por hematoxilina de Harris e Eosina (HE). A temperatura da água variou de 25,5 a $33,6^{\circ} \mathrm{C}$ e a salinidade de 21,1 a 34,3 Unidades Práticas de Salinidade (UPS). Os espécimens mediram entre 41,1 e 68,6 mm e tiveram um peso médio de 7,24 g. Macroscopicamente, não se observou presença do parasito ou qualquer alteração morfológica relacionada à presença do mesmo. A frequência percentual de Nematopsis sp. foi de 99,45\%. O manto foi o órgão de maior frequência de infecção (46,26\%), seguido das gônadas (18,36\%). Entre os órgãos analisados, todos apresentaram o parasito, sendo que, para poucos casos severamente infectados, observaram-se microscopicamente modificações na conformação do manto. A intensidade de infecção para a maioria das sessões analisadas foi de 1 a 3 oocistos/fagócitos, contudo em uma das sessões foram registrados 9 oocistos/fagócitos. O parasito apresentou correlação negativa com a salinidade. A elevada frequência do Nematopsis sp. deve ser levada em consideração para a sustentabilidade dos estoques naturais, principalmente se tal parasitismo ocorrer simultaneamente a outros patógenos e condições ambientais estressantes.

Palavras-chave: Bivalves. Parasitismo. Área de proteção ambiental. Protozoário. Sustentabilidade ambiental. 
Correspondence to:

Valéria Macedo Almeida Camilo

Universidade Federal do Recôncavo da Bahia, Centro de

Ciências da Saúde

Avenida Carlos Amaral, $\mathrm{n}^{\circ} 1024$ - Cajueiro

CEP 44574-520, Santo Antônio de Jesus, BA, Brazil

e-mail:vcamilo@ufrb.edu.br

Received: $11 / 04 / 2018$

Approved: 03/09/2018

\section{Introduction}

Estuaries across the coast of the State of Bahia are inhabited by various species of bivalves, among which the Mytella guyanensis (Lamarck, 1819) is highlighted, being part of a group of marine invertebrates with socioeconomic importance and popularly known as "sururu", "bico de ouro/golden beak" and "bacucu" (RIOS, 1994). In the Pacific Ocean, this species is distributed from Mexico to Peru, and from Venezuela to Brazil in the Atlantic Ocean (RIOS, 2009).

Mytella guyanensis represents an economic alternative for coastal populations, as develop quickly, especially in the Northeast Region of Brazil, due to the tropical temperatures (25-30 $\left.{ }^{\circ} \mathrm{C}\right)$ (QUEIROGA et al., 2015). In addition, it is a food that contributes to the food safety of these populations, as it is a source of proteins and micronutrients (CAMILO et al., 2018).

One of the impediments to the growth and development of bivalves is the presence of parasitism and associated diseases, which diminish the growth potential, spoiling the efficiency of metabolic processes and the development and reproduction of the species. Besides, they become more vulnerable to stressful situations, significantly reducing the level of adaptation to environmental factors, resulting in reduced chances of survival (BOEHS et al., 2010).

Parasites, mainly the protozoa, may infect most of the bivalves from intertidal zones, using them as hosts since some of these present epizootic potential, which may cause mass mortality (BOEHS et al., 2012).

The protozoa are amongst the main causing agents of diseases in marine bivalves, being the ones from the Genus Nematopsis Schneider, 1892 (Apicomplexa: Eugregarinida), the most important. These are intrahemocytic parasites, having the oocyst as infecting form, which contains a single sporozoite. In the bivalve, this infectious agent may parasite various organs, such as the mantle, gills, the digestive gland, the musculature, and the gonads (BOEHS et al., 2012).

Records about the Nematopsis spp. in bivalves include various hosts, such as Crassostrea rhizophorae, C. gigas, C. virginica, Perna perna, P. canaliculus, Cerastoderme edule, Ruditapes decussatus and Mytella guyanensis. These species are present in several regions, what intensifies the concern regarding the risk of diffusion of this parasite across the world. (BOEHS et al., 2012).

The pathogenicity of Nematopsis spp. is still quite debated, possibly due to the degree of parasitism in the host (NASCIMENTO et al., 1986; BRITO et al., 2010). Such protozoa have the bivalves as intermediary hosts, completing their life cycle in crustaceans (LAUCKNER, 1983; BOWER, 1992; AZEVEDO; MATOS, 1999; CARBALLAL et al., 2001). Thus, the occurrence of this parasite in bivalves is associated with the presence of crustaceans in the same habitat (BOEHS et al., 2010), leading to a higher infection susceptibility, increased stress level, and risk of mortality.

Over the last 15 years, studies have been conducted in several regions, such as in the Atlantic Coast (CREMONTE et al., 2005), in the Gulf of Mexico (AGUIRRE-MACEDO et al., 2007), in Brazil (PINTO; BOEHS, 2008; CEUTA; BOEHS, 2012; COEN; BISHOP, 2015; NUNES, 2016), aimed at evidencing the presence of this parasite in bivalves, raising awareness on the possible risk of propagation that has generated concern regarding the environmental sustainability.

Thus, this research aims at investigating the parasitism by Nematopsis sp. in M. guyanensis extracted from a mangrove in the Marine Extractive Reserve (RESEX) Baía do Iguape, Bahia, Brazil.

\section{Material and Methods}

\section{Area of Study and Sample Design}

This study was carried out in the north sector of the Marine RESEX Baía do Iguape, in the estuary of the Engenho da Ponte River (12 $38^{\prime} 50^{\prime \prime}$ S and $38^{\circ} 51^{\prime} 43^{\prime \prime} \mathrm{W}$ ) (Figure 1), in the city of Cachoeira, Bahia, Brazil.

Specimens were collected by hand, monthly, from March 2014 to March 2015, in a mangrove area of the estuarine region of Baía do Iguape (Figure 1), consisting of 30 specimens/month $(\mathrm{n}$ total $=360)$. The specimens' height was above $40 \mathrm{~mm}$ (SIBAJA, 1986) and they were obtained during low tide periods. 


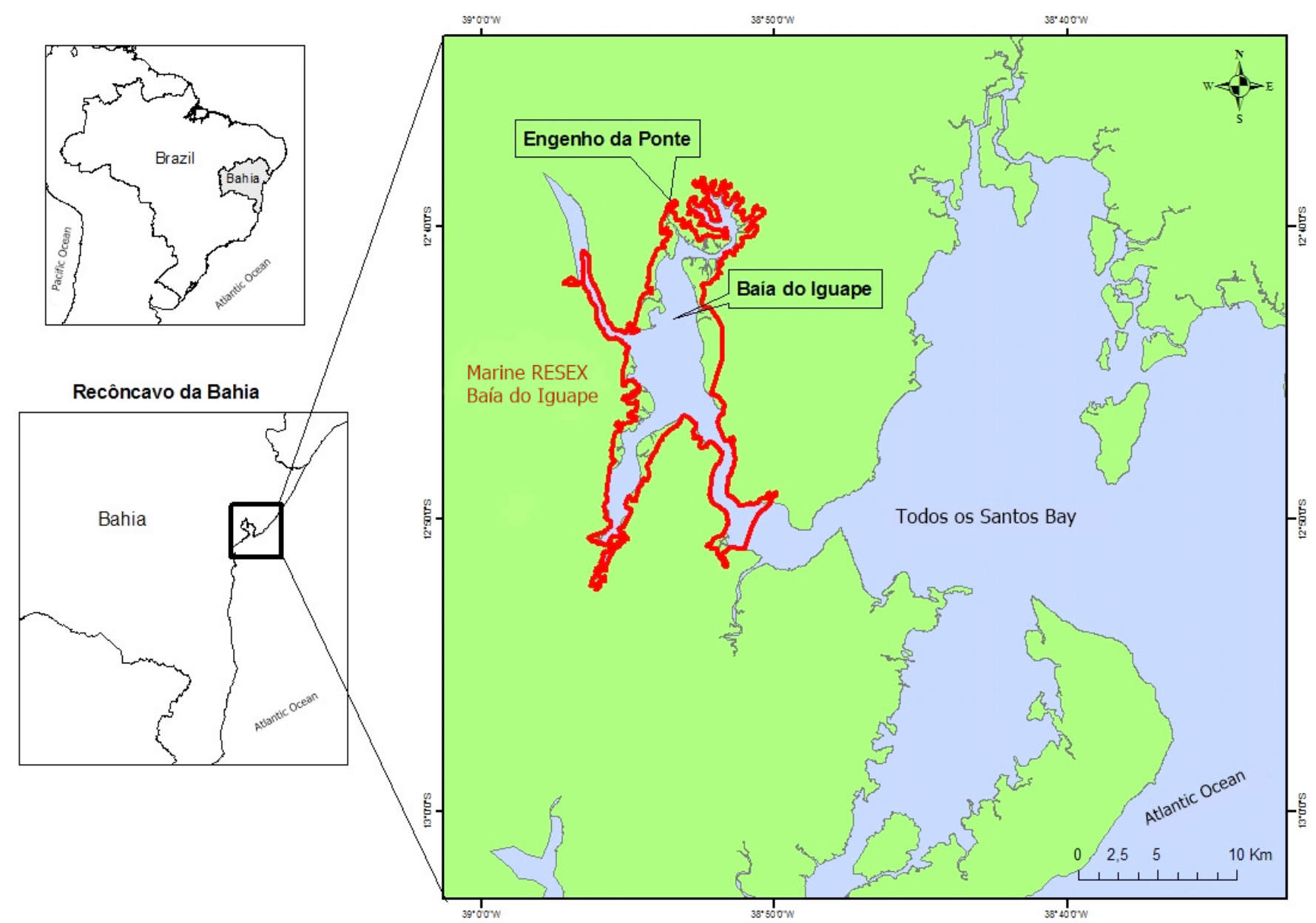

Figure 1 - Map of Brazil, with the State of Bahia highlighted, indicating the place where samples were collected in the Marine RESEX Baía do Iguape, 2015

They were transported in labeled recipients and processed in the Microbiology Laboratory of the Federal University of Reconcavo da Bahia (Santo Antônio de Jesus, Bahia) and in the Histology Laboratory of the Oswaldo Cruz Foundation. The identification of the tide stage was made by consulting the Tide Table of the Directorate of Hydrography and Navigation of the Brazilian Navy (BRASIL, 2015). All of the animals in this study were collected in conformity with specific federal authorizations emitted by the Ministry of Environment and approved by the Biodiversity Information and Authorization System - SISBIO under License no. 42081-1.

\section{Abiotic Factors}

In parallel with the biological sampling campaigns, a monitoring of the water temperature and salinity was carried out in the region of collection, using a portable Water Quality Meter AK88 (Akso ${ }^{\circ}$ ) multiparameter meter. Monthly pluviometry data were obtained by the National Institute for Space Research - INPE, 2014, based on the city of Cachoeira, Bahia, Brazil.

\section{Biometry}

Specimens were measured by their shell height (anteroposterior axis). A digital caliper with $0.01 \mathrm{~mm}$ precision was used. The samples were also weighed on an analytical scale with $0.001 \mathrm{~g}$; subsequently, they were opened and macroscopically examined to identify parasites and/or signs of morphological alterations.

\section{Histological Processing and Parasitological Analysis}

A section from the tissue was diagonally removed in the visceral mass of each specimen, thus sampling the mantle, gonad, gill, digestive gland, and foot. The material was fixed in Davidson solution (SHAW; BATTLE, 1957) and, after 24 hours, transferred to a $70 \%$ ethanol solution, being processed according to classic histological techniques. Cuts of $5 \mathrm{~m}$ thickness were obtained by microtomy, followed by Harris' Hematoxylin and Eosin staining (HE) (HOWARD; SMITH, 2004).

Histological sessions were examined and described regarding the presence of morphological alterations, presence of Nematopsis sp., and places of infection; 
after that, they were photomicrographed using a light microscope with a camera attached (Leica DM 500').

\section{Statistical Analysis}

Parasite frequency percentage was calculated as the number of specimens infected/total number of specimens collected (MEDRONHO, 2009). The infection intensity was calculated from the visual field count. Variables were tested as to normality and homogeneity of variances through the Kolmogorov-Smirnov test. Descriptive statistics were carried out for abiotic data. To verify the correlation degree between the parasitized tissues and abiotic parameters, the Spearman correlation test was performed (significance limit of 0.05). Statistical analyses were made using the software Excel and SPSS, v. 23.

\section{Results}

\section{Abiotic Factors}

The water temperature ranged from $25.5^{\circ} \mathrm{C}$ to $33.6^{\circ} \mathrm{C}$ $\left(29.7 \pm 2.4^{\circ} \mathrm{C}\right)$ and salinity from 21.1 PSU (Practical Salinity Unit) to 34.3 PSU (27.1 \pm 3.5 PSU) (Figure 2). The lowest value of salinity occurred in August 2014, a period that had the highest rate of rainfall precipitation (Figure 3).

Analyzing the abiotic factors (temperature, salinity, and rainfall), salinity was the only parameter that presented a negative correlation with the presence of parasites in the organs (except in the gills); hence, one can see a tendency of increased parasitized tissues in low salinity (Table 1).

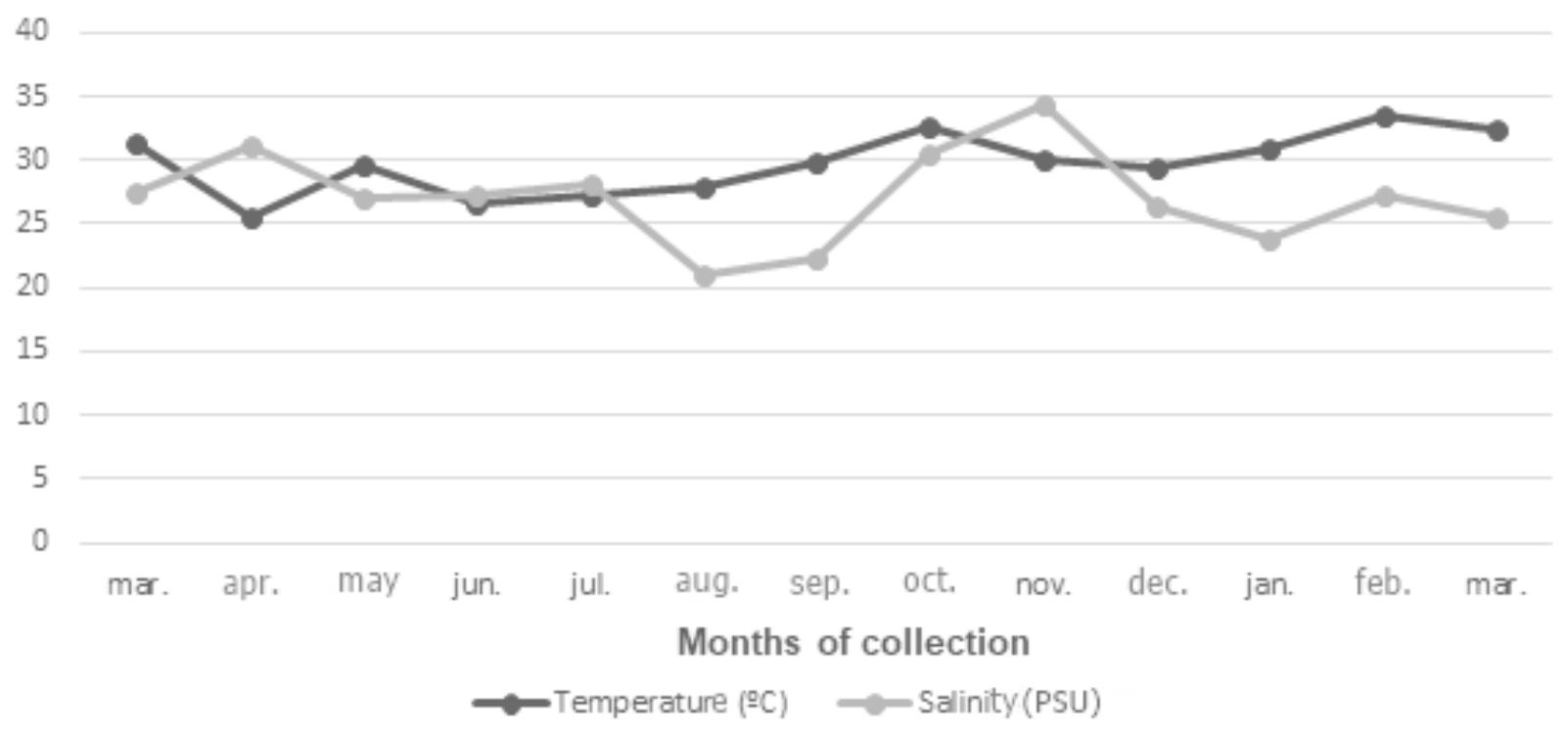

Figure 2 - Variation of temperature $\left({ }^{\circ} \mathrm{C}\right)$ and salinity (PSU) in the estuarine water of Baía do Iguape, Cachoeira (BA), from March 2014 to March 2015

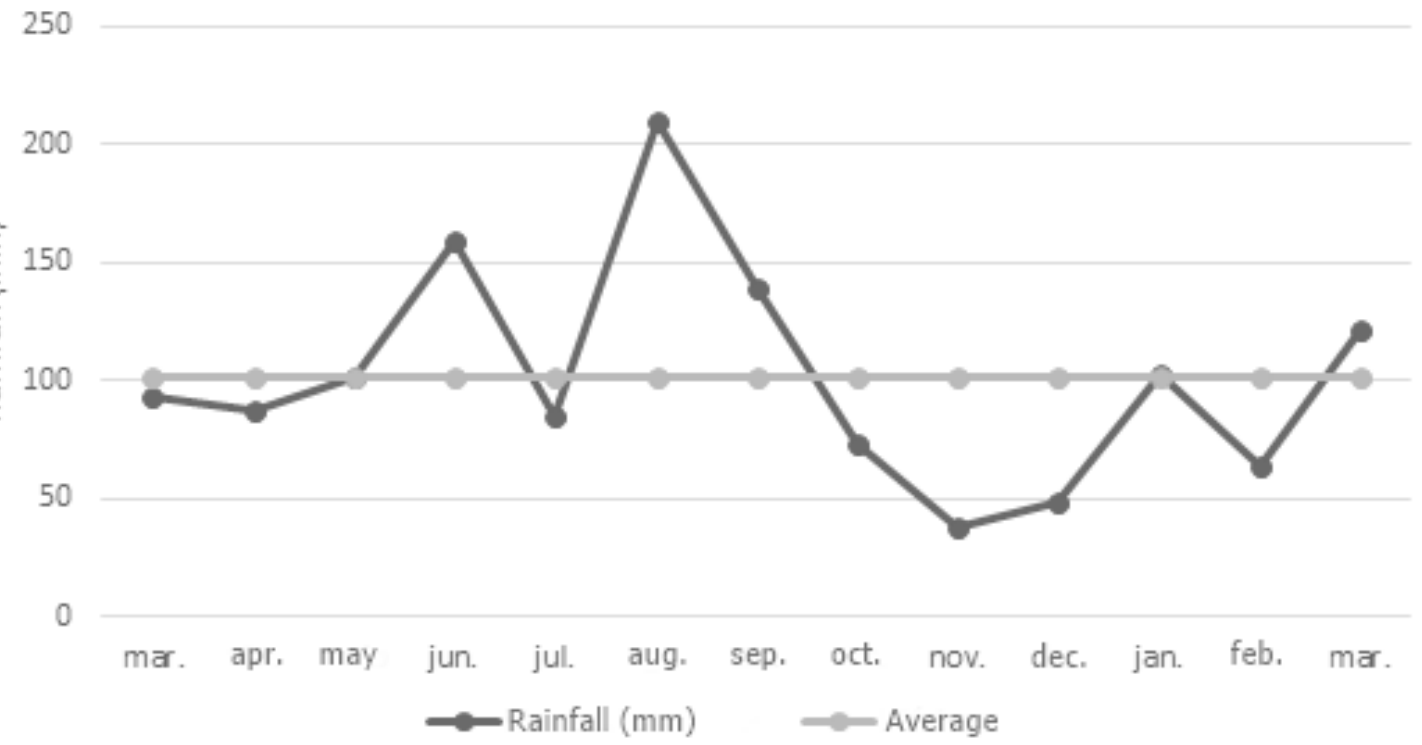

Figure 3 - Rainfall variation (mm) in the estuarine region of Baía do Iguape, Cachoeira (BA), from March 2014 to March 2015 
Table 1 - Correlation between abiotic and parasitized factors in Mytella guyanensis, collected in Baía do Iguape from March 2014 to March 2015

\begin{tabular}{lcc}
\hline \multicolumn{1}{c}{ Organ } & Parameter & $\mathbf{r}_{\mathbf{s}}$ \\
\hline Mantle & Salinity & $-0.105^{*}$ \\
Digestive gland & Salinity & $-0.156^{* *}$ \\
& Rainfall & $0.167^{* *}$ \\
Foot & Temperature & $0.141^{* *}$ \\
Gonad & Temperature & $0.170^{* *}$ \\
& Salinity & $-0.197^{* *}$ \\
\hline
\end{tabular}

** $\mathrm{P}<0.01$

${ }^{*} \mathrm{P}<0.05$

\section{Biometry}

The specimens measured between 41.1 and $68.6 \mathrm{~mm}$ (Mean: $50.64 \pm 4.98 \mathrm{~mm}, \mathrm{n}=360$ ). The minimum weight was $4.35 \mathrm{~g}$, whereas the maximum was $19.46 \mathrm{~g}$ (mean: 7.24 $\mathrm{g} \pm 3.07 \mathrm{~g}$ ). There was no microscopic evidence such as texture alteration or stained tissues, which would indicate the presence of parasites.

\section{Histological Processing and Parasitological Analysis}

The frequency percentage of Nematopsis sp. was $99.45 \%$ (360/358); therefore, an expressive presence of this parasite was assessed during the entire process of this study. The frequency did not reach 100\% only in October 2014 and January 2015; however, it was still around 96\% (Figure 4).

The mantle was the most infected organ (46.26\%), followed by the gonads (18.36\%), foot (12.06\%), gills (11.95\%), and digestive gland (11.35\%).

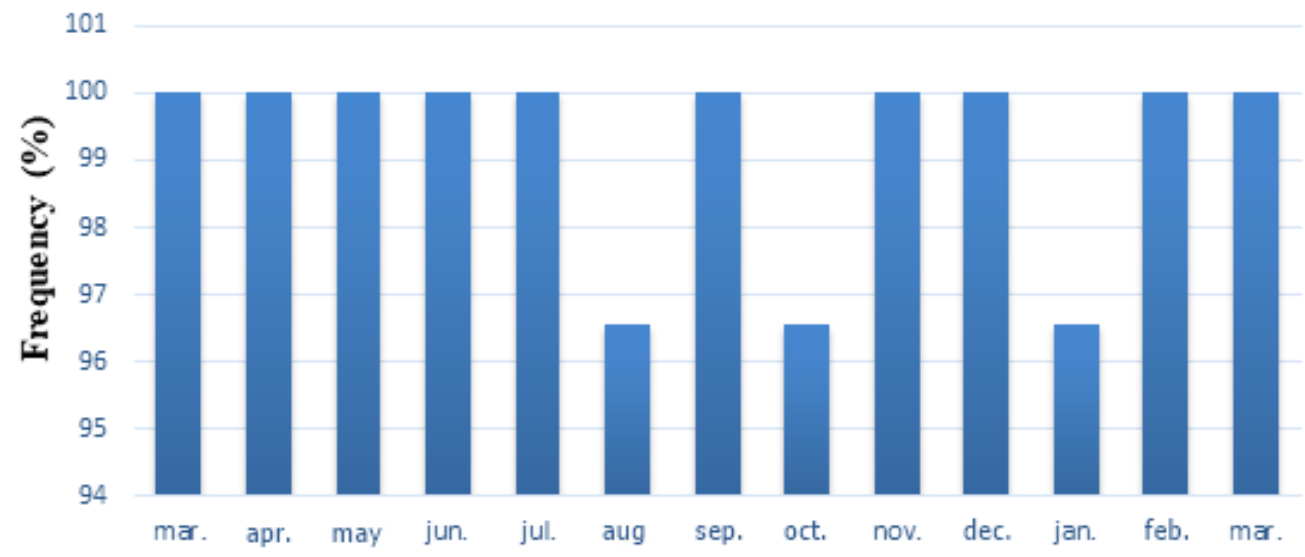

\section{Months of collection}

Figure 4 - Frequency percentage of infection by Nematopsis sp. in Mytella guyanensis in the estuarine region of Baía do Iguape, Cachoeira (BA), from March 2014 to March $2015(\mathrm{n}=360)$

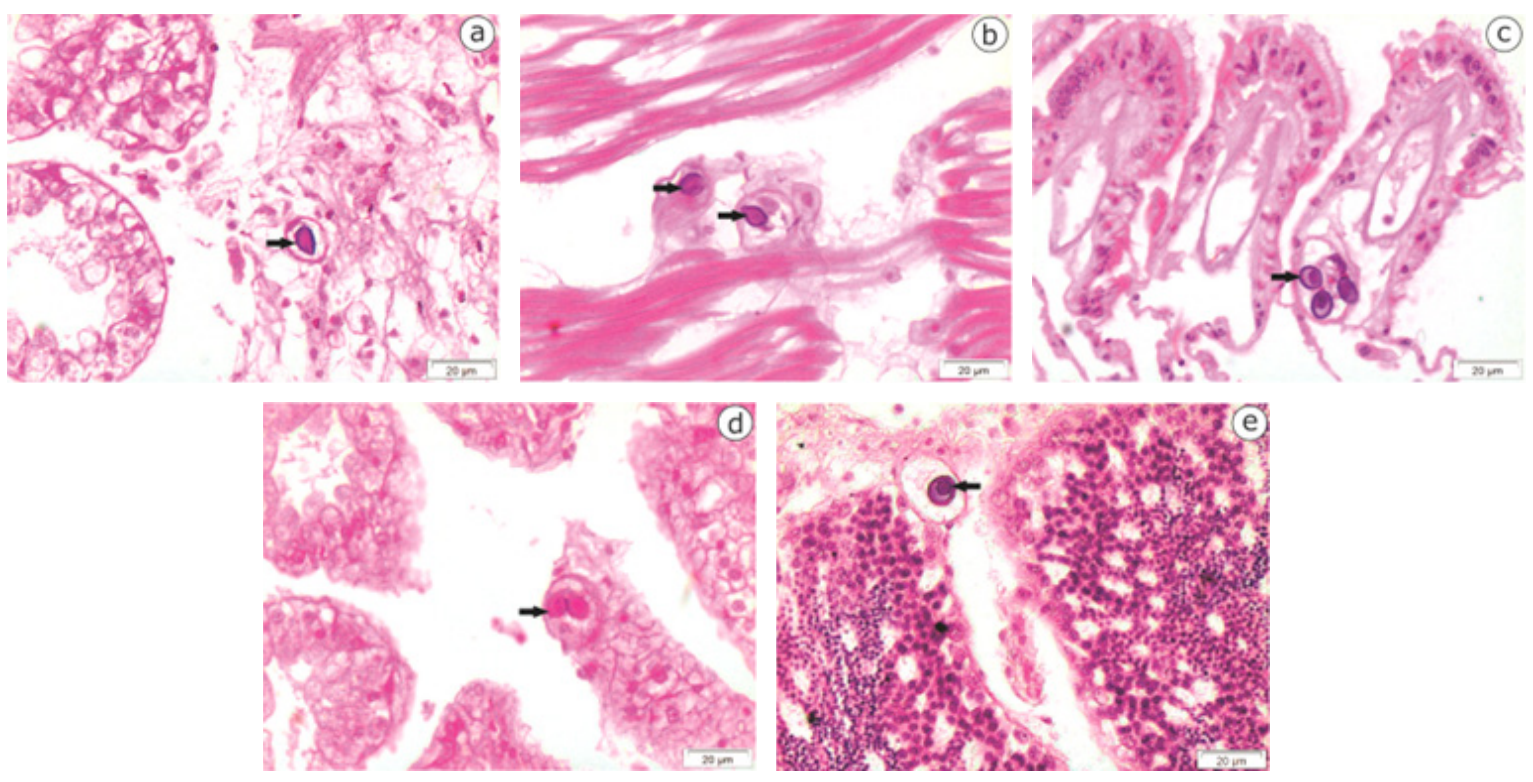

Figure 5 - Photomicrographs of Mytella guyanensis with the occurrence of Nematopsis sp. (arrows) in different places of infection. a) mantle; b) foot; c) gills; d) digestive gland; e) male gonad. Estuarine region of Baía do Iguape, Cachoeira (BA), from March 2014 to March 2015

Bar $=20 \mu \mathrm{m}$. Staining: HE. 
Severely infected specimens presented microscopical modifications in the conformation of the mantle, next to the labial palp; however, such findings represented a small number of cases (0.55\%) (Figure 6).
The number of oocytes was usually 1 to 3 by phagocyte; nonetheless, in one of the analyzed cuts, in the mantle of a female (next to the gonad), 9 oocytes/phagocyte were found (Figure 7).
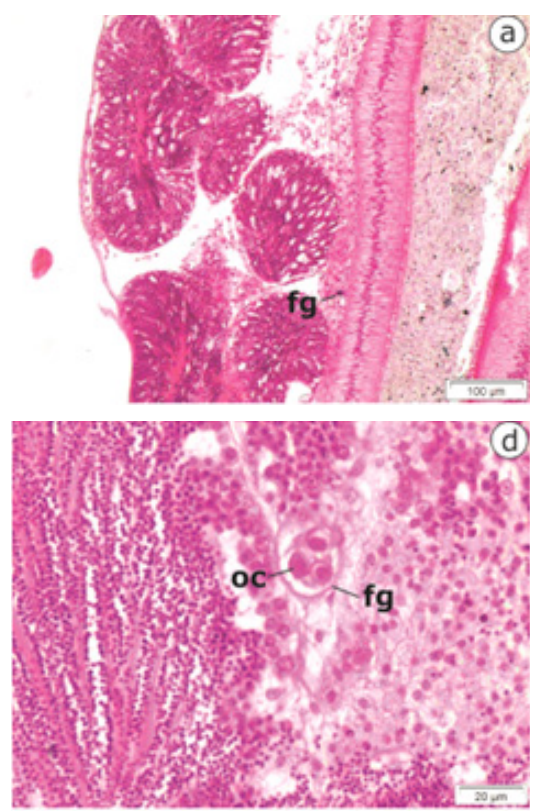
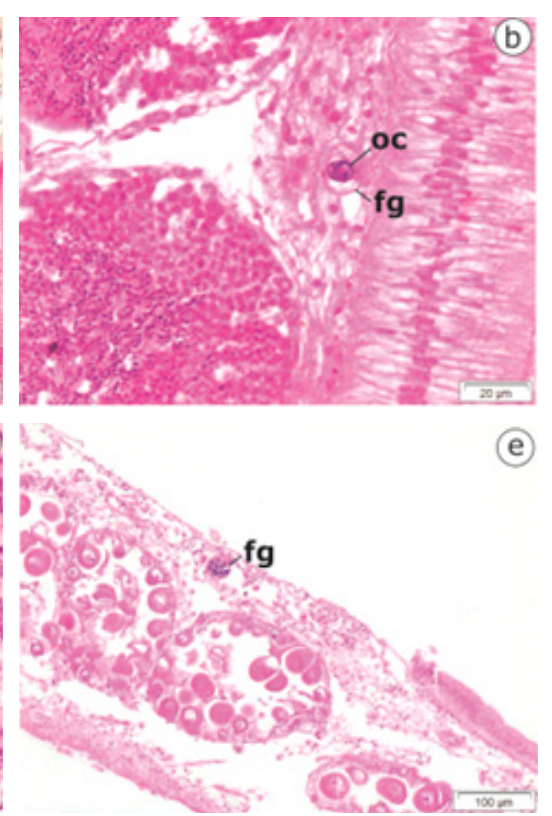

(e)
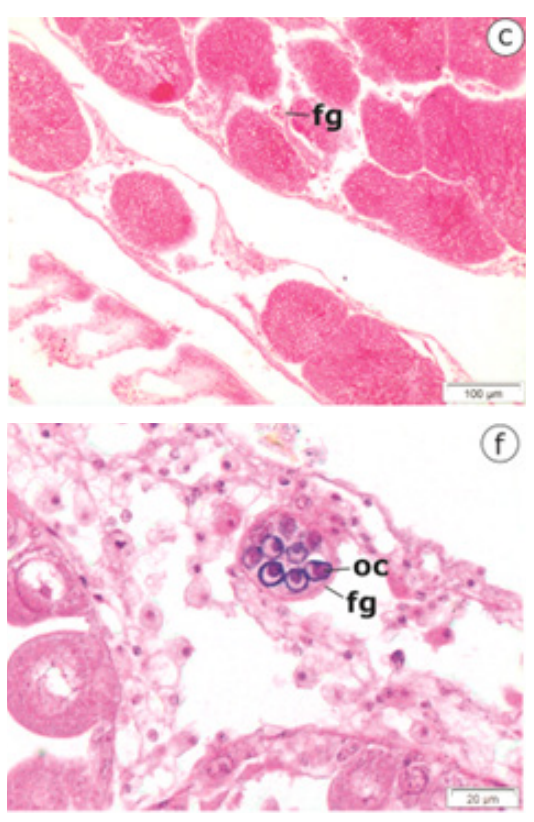

Figure 6 - Photomicrographs of Mytella guyanensis from the estuarine region of Baía do Iguape, Cachoeira (BA), from March 2014 to March 2015 ( $n=360)$, showing the number of Nematopsis sp. oocysts by phagocyte in several organs. Oc: Oocyst. Fg: phagocyte

Bar $=100 \mu \mathrm{m}$ and $20 \mu \mathrm{m}$. Staining: HE.
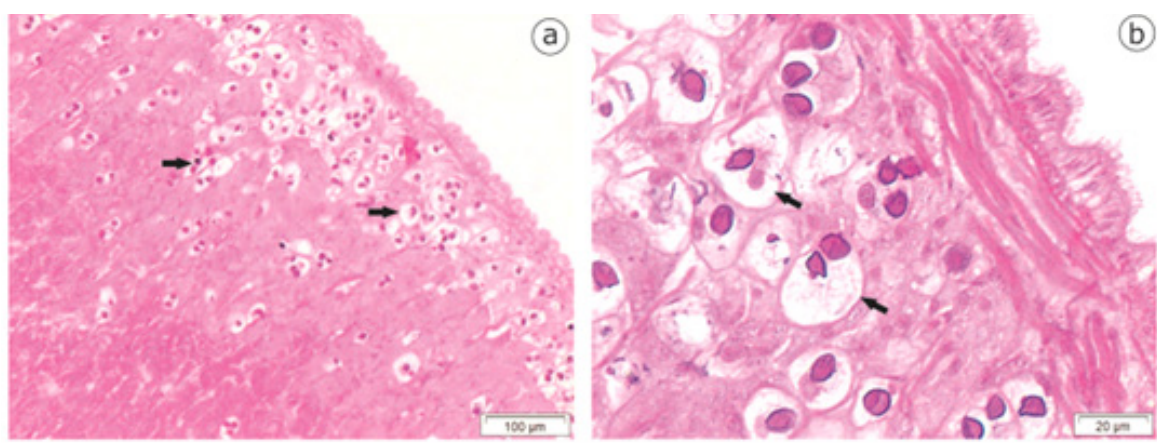

(b)

Figure 7 - Photomicrographs of Mytella guyanensis from Baía do Iguape, Cachoeira (BA), from March 2014 to March 2015, with various phagocytes (arrows) on labial palps, evidencing mantle destruction

Bar $=100 \mu \mathrm{m}$ and $20 \mu \mathrm{m}$. Staining: HE.

\section{Discussion}

One of the main abiotic factors that favored the distribution of marine organisms in estuaries is the salinity. Mytella guyanensis, as an euryhaline species, can withstand a wide variation of salinity (SIBAJA, 1986), even though it presents distinct behaviors for higher and lower variations (YUAN et al., 2010). According to Lauckner (1983), salinity is a determining factor in the abundance of parasites and in the survival of bivalves regarding diseases. The correlation between parasitism and salinity may be justified by the existing association between this abiotic parameter and the bivalve health state. Thus, according to Coen and Bishop (2015), as a bivalve defense mechanism against the increase of salinity, this restricts the capture and filtration of organic particles and, therefore, it tends to remain immunosuppressed. However, such condition does not seem to harm the parasites.

In this study, the water temperature presented variation characteristic of tropical regions, of small amplitude, similar to what was found in the studies developed by Silva et al. (2004), Martins et al. (2009), and Oliveira (2014) in estuarine waters of the Northeast Region of Brazil. 
Protozoa of Genus Nematopsis sp. are parasites frequently reported by their elevated frequency in bivalves (BOEHS et al., 2012); in the southern region of Bahia, Pinto and Boehs (2008) found a $80 \%$ frequency of occurrence of this parasite in M. guyanensis, values close to those observed in this study.

Despite of the infection by Nematopsis sp. being associated to a focal hemocytic reaction without significant effects to the bivalve health, as verified in studies in the state of Bahia (COVA et al., 2015), Paraíba (QUEIROGA et al., 2015), and Sergipe (SILVA et al., 2015). Azevedo and Cachola (1992) showed that high levels of infection by Nematopsis sp. may lead to complete destruction of the gills, degeneration of host cells, and death. In a study carried out by Francisco et al. (2010), it was found, in the gills and labial palps of adult bivalves, architectural disorganization of tissues, hemocyte infiltration, and lamellar hyperplasia when they were infected by Nematopsis sp. Both Ceuta and Boehs (2012) observed alterations of labial palps in highlyinfected specimens.

As for the histopathological signs of reaction to the parasite, the tissue changes verified in some specimens were also reported by Sabry et al. (2007) in oysters of the species Crassostrea rhizophorae from the state of Ceará. With this study, a small number of cases of modifications in the mantle conformation of the $M$. guyanensis was perceived at microscopic level, condition that is similar to that found by Pinto and Boehs (2008) in a research in the estuarine region of Cachoeira River, Ilhéus, Bahia.

Nematopsis is an intra-parasite, occurring within phagocytes, which present oocysts in quantity that may vary up to twenty, more commonly from one to three oocysts/phagocyte, a result that corroborates the findings of this study. Each oocyst contains a single sporozoite, which is characteristic of the gregarines (BOEHS et al., 2009).

\section{References}

AGUIRRE-MACEDO, M. L.; SIMÁ-ÁLVAREZ, R. A.; ROMÁN-MAGAÑA, M. K.; GÜEMEZ-RICALDE, J. I. Parasite survey of the eastern oyster Crassostrea virginica in Coastal Lagoons of the Southern Gulf of Mexico. Journal of Aquatic Animal Health, v. 19, n. 4, p. 270279, 2007. doi: 10.1577/H06-050.1.

AZEVEDO, C.; CACHOLA, R. Fine structure of the apicomplexa oocyst of Nematopsis sp. of two marine bivalve molluscs. Diseases of Aquatic Organisms, v. 14,
The mantle and gonads are the places most commonly infected by the Nematopsis sp., which can be justified by the fact the M. guyanensis is a bivalve with high percentages of proteins (collagen), vitamin (vitamin A), and the mineral zinc, explainin the presence of parasite in these places that most likely assure their nutrition (LIRA et al., 2004; SANTOS et al., 2014).

Considering the importance of bivalves regarding social and environmental aspects for coastal communities (SANDE et al., 2010), various factors may present a risk to the preservation of natural stocks and consequent environmental unsustainability. So far, there is not a positioning as to the pathogenic potential of the parasite in question or to its degree of mortality; however, the inexistence of this information does not discard the need for monitoring.

\section{Conclusion}

In this study, alterations in the mantle morphology were observed in some severely infected specimens, even though such findings represent a small number of cases. However, the elevated percentage frequency recorded must be considered for the sustainability of natural stocks, mainly if such parasitism occurs simultaneously with other pathogens and with stressful environmental conditions. The regular monitoring of natural stocks is recommended to avoid losses and damages to the environment.

\section{Conflicts of interest}

The authors declare no conflicts of interest.

\section{Acknowledgement}

The authors thank the Bahia State Research Support Foundation (Fundação de Amparo à Pesquisa do Estado da Bahia - FAPESB) for financing the project (TSC0021/2012) and to the Gonçalo Muniz/Fiocruz Laboratory for the preparation of blades.

p. $69-73,1992$. Available from: $<$ https://www.int-res.com/ articles/dao/14/d014p069.pdf>. Viewed: Nov. 16th, 2018.

AZEVEDO, C.; MATOS, E. Description of Nematopsis mytella n. sp. (Apicomplexa), parasite of the mussel Mytella guyanensis (Mytelidae) from the Amazon Estuary and Description of its Oocysts. European Journal of Protistology, v. 35, n. 4, p. 427-433, 1999. doi: 10.1016/S0932-4739(99)80052-2. 
BOEHS, G.; LENZ, T. M.; VILLALBA, A. Xenomas in Crassostrea rhizophorae (Ostreidae) from Camamu Bay, Bahia, Brazil. Brazilian Journal of Biology, v. 69 , n. 2, p. $457-458,2009$. doi: 10.1590/S151969842009000200032 .

BOEHS, G.; MAGALHÃES, A. R. M.; SABRY, R. C.; CEUTA, L. O. Parasitas e patologias de bivalves marinhos de importância econômica da costa brasileira. In: SILVA-SOUZA, A. T.; LIZAMA, M. A. P.; TAKEMOTO, R. M.; JATOBÁ, A. (Org.). Patologia e Sanidade de Organismos Aquáticos. Maringá: Massoni, 2012. p. 165-194.

BOEHS, G.; VILLALBA, A.; CEUTA, L. O.; LUZ, J. R. Parasites of three commercially exploited bivalve mollusc species of the estuarine region of the Cachoeira River (Ilhéus, Bahia, Brazil). Journal of Invertebrate Pathology, v. 103, n. 1, p. 43-47, 2010. doi: 10.1016/j. jip.2009.10.008.

BOWER, S. M. Diseases and parasites of mussels. In: GOSLING, E. The Mussel Mytilus: ecology, physiology, genetics and culture. Amsterdam: Elsevier, 1992. p. 543-563.

BRASIL. Marinha do Brasil. Centro de Hidrografia. Tábuas de Maré, 2015. Available from: <https://www. marinha.mil.br/>. Viewed: Nov. 5, 2015.

BRITO, L. O.; BARROS, J. C. N. D.; GÁlVEZ, A. O.; BARROS, F. N. D. Presence of Nematopsis sp. (Protozoa, Apicomplexa) in the oyster, Crassostrea rhizophorae (Guilding, 1828), cultivated in the state of Pernambuco, Brazil. World Aquaculture, v. 41, n. 1, p. 60-62, 2010.

CAMILO, V. M. A.; SOUZA, J. C.; CONCEIÇÃO, E. J.; LUZ, J. R.; BOEHS, G.; CAMPIOLO S. Reproductive cycle of Mytella guyanensis (Lamarck, 1819) in a Marine Reserve (RESEX Bay of Iguape), Bahia, Brazil. Brazilian Journal of Biology, v. 78, n. 8, p. 255-264, 2018. doi: 10.1590/1519-6984.05716.

CARBALLAL, M. J.; IGLESIAS, D.; SANTAMARINA, J.; FERRO-SOTO, B.; VILLALBA, A. Parasites and Pathologic Conditions of the Cockle Cerastoderma edule Populations of the Coast of Galicia (NW Spain). Journal of Invertebrate Pathology, v. 78, n. 2, p. 87-97, 2001. doi: 10.1006/jipa.2001.5049.
CEUTA, L.; BOEHS, G. Parasites of the mangrove mussel Mytella guyanensis (Bivalvia: Mytilidae) in Camamu Bay, Bahia, Brazil. Brazilian Journal Biology, v. 72, n. 3, p. 421-427, 2012. doi: 10.1590/S151969842012000300002 .

COEN, L. D.; BISHOP, M. The ecology, evolution, impacts and management of host-parasite interactions of marine molluscs. Journal of Invertebrate Pathology, v. 131, p. 177-211, 2015. doi: 10.1016/j.jip.2015.08.005.

COVA, A. W.; SERAFIM JÚNIOR, M.; BOEHS, G.; SOUZA, J. M. D. Parasites in the mangrove oyster Crassostrea rhizophorae cultivated in the Graciosa river estuary in Taperoá, Bahia. Brazilian Journal of Veterinary Parasitology, v. 24, n. 1, p. 21-27, 2015. doi: 10.1590/S198429612015012.

CREMONTE, F.; FIGUERAS, A.; BURRESON, E. M. A. histopathological survey of some commercially exploited bivalve molluscs in northern Patagonia, Argentina. Aquaculture, v. 249, n. 1-3, p. 23-33, 2005. doi: 10.1016/j. aquaculture.2005.01.024.

FRANCISCO, C. J.; HERMIDA, M. A.; SANTOS, M. J. Parasites and Symbionts from Mytilus galloprovincialis (Lamark, 1819) (Bivalves: Mytilidae) of the Aveiro Estuary Portugal. Journal of Parasitology, v. 96, n. 1, p. 200-205, 2010. doi: 10.1645/GE-2064.1.

HOWARD, D. W.; SMITH, C. S. Histological Techniques for Marine Bivalve Mollusks. Woods Hole. Massachusetts: U.S. Department of Commerce, 2004.

INSTITUTO NACIONAL DE PESQUISAS ESPACIAIS INPE. Proclima. Programa de Monitoramento em tempo real do Clima de Região Nordeste. Cachoeira Paulista, SP: INPE/CPTEC, 2014. Available from: <http://www.cptec. inpe.br>. Viewed: Jun. 20th, 2015.

LAUCKNER, G. Diseases of Mollusca: bivalvia. In: KINNE, O. (Ed.). Diseases of marine animals. Hamburg: Biologische Anstalt Helgoland, 1983. p. 477-879.

LIRA, G. M.; MANCINI-FILHO, J.; SANT'ANA, L. S.; TORRES, R. P.; OLIVEIRA, A. C.; OMENA, C. M. B. Perfil de ácidos graxos, composição centesimal e valor calórico de moluscos crus e cozidos com leite de coco 
da cidade de Maceió-Al. Revista Brasileira de Ciências, v. 40 , n. 4, p. 529-537, 2004 doi: 10.1590/S151693322004000400010 .

MARTINS, A. G. L. D. A.; NASCIMENTO, A. R.; VIEIRA, R. H. S. D. F.; SERRA, J. L.; ROCHA, M. M. R. M. Quantification and identification of Aeromonas spp. in surface waters of the Bacanga River estuary in São Luís, MA (Brazil). Bulletin of the Food Processing Research Center, v. 27, n. 1, p. 107-118, 2009. doi: 10.5380/ cep.v27i1.14957.

MEDRONHO, R. A. Epidemiology. São Paulo, Atheneu, 2009. $685 \mathrm{p}$.

NASCIMENTO, I. A.; SMITH, D. H.; KERN, F.; PEREIRA, S. A. Pathological findings in Crassostrea rhizophorae from Todos os Santos Bay, Bahia, Brazil. Journal of Invertebrate Pathology, v. 47, n. 3, p. 340-349, 1986. doi: 10.1016/0022-2011(86)90105-9.

NUNES, F. de F. V. Sanidade de ostras (Crassostrea rhizophorae) cultivadas na Reserva Extrativista Marinha Baía do Iguape, Bahia. 2016. 132 f. Tese (Doutorado) - Universidade Federal Rural de Pernambuco, Pós-Graduação em Ciência Animal Tropical, Recife, 2016.

OLIVEIRA, N. L. de. Avaliação do crescimento da ostra nativa Crassostrea (sacco, 1897) cultivada em estruturas de sistemas fixos nas localidades de Ponta Grossa (município de Vera Cruz) e Iguape (município de Cachoeira), região do Recôncavo, na Baía de Todos os Santos, Bahia, 2014. 70 f. Dissertação (Mestrado) Universidade Federal do Recôncavo da Bahia, Cruz das Almas, 2014.

PINTO, T. R.; BOEHS, G. Nematopsis sp. (Apicomplexa: Eugregarinida) in Mytella guyanensis (Lamarck, 1819) (Bivalvia: Mytilidae) from the Estuarine Region of Rio Cachoeira, Ilhéus, Bahia, Brazil. Brazilian Journal of Veterinary Research and Animal Science, v. 45, n. 2, p. 95-100, 2008. doi: 10.11606/issn.1678-4456. bjvras.2008.26705.

QUEIROGA, F. R.; VIANNA, R. T.; VIEIRA, C. B.; FARIAS, N. D.; SILVA, P. M. da. Parasites infecting the cultured oyster Crassostrea gasar (Adanson, 1757) in Northeast Brazil. Parasitology, v. 142, n. 6, p. 756-766, 2015. doi: 10.1017/S0031182014001863.

RIOS, E. C. Seashells of Brazil. Rio Grande: Fundação Cidade do Rio Grande, 1994. 330 p.

RIOS, E. C. Compendium of Brazilian Seashells. Rio Grande: Evangarf, 2009. 668 p.

SABRY, R. C.; GESTEIRA, T. C. V.; BOEHS, G. First record of parasitism in the mangrove oyster Crassostrea rhizophorae (Bivalvia: Ostreidae) at Jaguaribe River estuary - Ceará, Brazil. Brazilian Journal Biology, v. 67 , n. 4, p. $755-758$, 2007. doi: 10.1590/S151969842007000400024 .

SANDE, D.; MELO, T. A.; OLIVEIRA, G. S. A.; BARRETO, L.; TALBOT, T.; BOEHS, G.; ANDRIOLI, J. L. Prospecção de moluscos bivalves no estudo da poluição dos rios Cachoeira e Santana em Ilhéus, Bahia, Brasil. Brazilian Journal of Veterinary Research and Animal Science, v. 47, n. 3, p. 190-196, 2010. doi: 10.11606/issn.1678-4456. bjvras.2010.26854.

SANTOS, T. M. M.; SAWAYA, A. L.; SILVA, M. C. D.; SANTOS, A. F.; NETO, J. A. B.; FLORÊNCIO, T. M. M. T. Avaliação microbiológica e da concentração de vitamina A, ferro e zinco em preparações do molusco sururu (Mytella falcata). Demetra, v. 9, n. 3, p. 811-822, 2014. doi: 10.12957/ demetra.2014.9440.

SHAW, B. L.; BATTLE, H. I. The gross and microscopic anatomy of the digestive tract of the oyster Crassostrea virginica (Gmelin). Canadian Journal of Zoology, v. 35, n. 3, p. 325-347, 1957. doi: 10.1139/z57-026.

SIBAJA, W. J. Madurez sexual en el mejillon chora Mytella guyanensis (Lamarck, 1819) (Mollusca, Bivalvia) del manglar en Jicaral, Puntarenas, Costa Rica. Revista de Biologia Tropical, v. 34, n. 1, p. 151-155, 1986.

SILVA, A. I. M.; VIEIRA, R. H. S. F.; MENEZES, F. G. R.; FONTELES-FILHO, A. A.; TORRES, R. C. O.; SANT'ANNA, E. S. Bacteria of fecal origin in mangrove oysters (Crassostrea rhizophorae) in the Cocó River Estuary, Ceará State, Brazil. Brazilian Journal of 
Microbiology, v. 34, n. 1-2, p. 126-130, 2004. doi: 10.1590/ S1517-83822004000100021.

SILVA, P. M. da; SCARDUA, M. P.; VIEIRA, C. B.; ALVES, A. C.; DUNGAN, C. F. Survey of pathologies in Crassostrea gasar (Adanson, 1757) oysters from cultured and wild populations in the São Francisco Estuary,
Sergipe, Northeast Brazil. Journal of Shellfish Research, v. 34, n. 2, p. 289-296, 2015. doi: 10.2983/035.034.0210.

YUAN, W.; WALTERS, L. J.; SCHNEIDER, K. R.; HOFFMAN, E. Exploring the survival threshold: a study of salinity tolerance of the nonnative mussel Mytella charruana. Journal of Shellfish Research, v. 29, n. 2, p. 415422, 2010. doi: 10.2983/035.029.0218. 